\title{
Sea-level inundation and risk assessment along the south and southwest coasts of Sri Lanka
}

\author{
Lakshika Palamakumbure ${ }^{1}$, Amila Sandaruwan Ratnayake ${ }^{1,2^{*}}$, H. M. Ranjith Premasiri ${ }^{1}$, Nalin Prasanna Ratnayake ${ }^{1,3}$, \\ Jinadasa Katupotha ${ }^{4}$, Nimila Dushyantha', Shanaka Weththasinghe ${ }^{1}$ and W. A. Panchala Weerakoon ${ }^{1}$
}

\begin{abstract}
Global sea-level changes have been a major topic among scientists. Sea-level changes are not globally uniform. Reconstruction of paleo sea-level changes and monitoring of variations in regional sea-level are important to (i) evaluate future sea-level changes, and (ii) predict risk assessment. In this study, we examined sea-level inundation during the middle Holocene highstands based on paleo sea-level indicators along the south and southwest coasts of Sri Lanka. Besides, future sea-level inundation was predicted considering the calculated sea-level trends based on tidal gauge data and high-resolution surface elevation data. Light Detection and Ranging (LiDAR) is one of the most accurate optical remote sensing methods currently available to obtain high-resolution land surface elevation data. Therefore, in this study, Digital Elevation Models (DEMs) were prepared using LiDAR data for estimating the risk assessment in coastal lowlands. Tide gauge data of Colombo in Sri Lanka (from 2006 to 2017), Gan in the Maldives (from 1995 to 2017), and Hulhule in the Maldives (from 1995 to 2017) showed that sea-level has increased with a rate of $0.288 \pm 0.118,0.234 \pm 0.025$, and $0.368 \pm 0.027 \mathrm{~mm} / \mathrm{month}$, respectively. DEMs based on LiDAR data suggested that south and southwest coasts are a risk of future sea-level inundation (height $=0.1-0.2 \mathrm{~m}$ during next 50 years and about $0.7 \mathrm{~m}$ in height during next 200 years, and distance = about $3.5-15.0 \mathrm{~m}$ from the present sealevel towards the inland). Consequently, it is important to consider future sea-level changes in disaster management and mitigation activities along the south and southwest coasts of Sri Lanka.
\end{abstract}

Keywords: Tidal data, LiDAR data, The Indian Ocean, Sea-level change, Disaster management

\section{Introduction}

The global sea-level has increased due to many reasons, such as thermal expansion of seawater due to the global warming (Wigley and Raper 1987; Bindoff et al. 2007; Domingues et al. 2008), and the input of freshwater from melting ice mass from Antarctica and Greenland (Meier et al. 2007; Huybrechts et al. 2011; Slangen and Lenaerts 2016). Even a small-scale sea-level rise can cause disastrous impacts, as coastal

\footnotetext{
*Correspondence: as_ratnayake@uwu.ac.lk

'Department of Earth Resources Engineering, Faculty of Engineering,

University of Moratuwa, Katubedda 10400, Sri Lanka

${ }^{2}$ Faculty of Applied Sciences, Uva Wellassa University, Passara Road, Badulla 90000, Sri Lanka

Full list of author information is available at the end of the article
}

areas are normally densely populated. Consequently, many studies have been undertaken to identify causes, trends, and patterns of future sea-level inundation and its risk management (e.g., Gregory et al. 2001; Caccamise et al. 2005; He et al. 2016).

Sea-level rise is not globally uniform, and differs from region to region followed by changes in atmospheric and/or oceanic circulation (Woodworth et al. 2009; Li and Han 2015), changes in the gravitational field of the Earth (Kang et al. 2005), and inverse barometer effect created by the atmospheric surface pressure changes (Wunsch and Stammer 1997). Besides, it is important to understand regional sea-level variations and local changes to predict future sea- 
level inundation and its risk assessment (e.g., Bindoff et al. 2007; Unnikrishnan and Shankar 2007; Han et al. 2010). A combined ground and satellite observations and simulations of Indian Ocean sea-levels have identified a clear spatial pattern in sea-level rise since the 1960s (Han et al. 2010). According to the tidal gauge data, sea-level has increased about $12.9 \mathrm{~cm}$ per century along the coasts of the north Indian Ocean (Unnikrishnan and Shankar 2007). Han et al. (2010) also identified that the coastlines of the Bay of Bengal, the Arabian Sea, Sri Lanka, Sumatra, and Java can experience particularly high sealevel rise due to the Indo-Pacific warm pool. The IndoPacific warm pool has warmed up by $0.5^{\circ} \mathrm{C}$ during the past decade. The average sea-level has thus been risen by 12.7 $\mathrm{mm}$ along the northern Indian Ocean coasts during the past decade (Han et al. 2010), making Sri Lanka one of the affected countries for coastal geoenvironmental disasters. Consequently, Sri Lanka is one of the hotspots to study future sea-level changes and risk assessment.

The detailed and accurate present land surface is required to predict potential erosion and inundation in response to sea-level rise. Light Detection and Ranging (LiDAR) is a remote sensing method that uses light in the form of a pulsed laser to measure the variable distance to the Earth. It can be used to obtain accurate landscape/topography of the Earth's surface (Hodgson and Bresnahan 2004). Therefore, the understanding of coastal geomorphology using the LiDAR method can be used to determine future sea-level inundation. Coastal geomorphological changes of Sri Lanka have been discussed by several authors (e.g., Katupotha 1988a, 1988b; Ratnayake 2016; Ratnayake et al. 2018; Amalan et al. 2018). However, studies on the regional sea-level rise and risk assessment based on local coastal geomorphology have rarely been focused in Sri Lanka.

The present study is focused on the most populated areas located in the south and southwest coasts of Sri Lanka. According to the Department of Census and Statistics of Sri Lanka, the study area consists of about 10\% of the total population in Sri Lanka. In this study, we first mapped areas for middle Holocene highstands based on paleo sea-level indicators. Then, the regional sea-level rising trend was calculated in the Indian Ocean using available tidal gauge data. Finally, future sea-level inundation and risk assessment maps were prepared considering the present landscape/topography and paleo sea-level evidence of the study area.

\section{Materials and methods}

\section{Paleo Sea-level indicators and middle Holocene Sea-level} inundation

The middle Holocene paleo sea-level indicators (e.g., inland coral reefs and marine shell beds) were identified and mapped during the extensive fieldwork along the south and southwest coasts of Sri Lanka. Global Positioning System (GPS) coordinates of all points were marked, and the middle Holocene sea-level inundation boundary was demarcated on topographic maps of the study area.

\section{Calculating sea-level changes}

Tide gauge data were used to calculate the sea-level changes. Colombo tide gauge is the only gauge available in Sri Lanka for a period of 11 years from 2006 to 2017. Two tide gauges in Gan in the Maldives (for the period of 22 years, from 1995 to 2017), and Hulhule in the Maldives (for the period of 22 years, from 1995 to 2017) were also selected from the near vicinity to the south and southwest coasts of Sri Lanka (Fig. 1). Distances from Colombo to Gan and Hulhule were approximately $990 \mathrm{~km}$ and $770 \mathrm{~km}$, respectively (Fig. 1). The sea-level trend for Sri Lanka was identified using the data from Colombo station, and it was compared to the Hulhule and Gan stations in the Maldives to analyze nearby regional trends. Daily sea-level data was obtained in csv format, and metadata were downloaded from the University of Hawaii Sea Level Center (UHSL) website. Monthly tidal data were obtained by averaging the daily data, and the missing values were replaced by repeating the value from the previous date. These data indicate seasonal variations, and it needs to be seasonally adjusted for identifying the trend. Therefore, the monthly tidal data have been seasonally adjusted for estimating the trend. Henderson filter-based method known as the 'ration to moving average' was used to adjust data seasonally (Macaulay 1931).

The original time series data (Ot) comprise the multiplicative fashion of seasonal component (St), trend-cycle component ( $\mathrm{Tt}$ ) and an irregular component (It). The seasonal component (St) is the variations in a time series representing intra-year fluctuations. The seasonal component (St) is more or less stable year after year concerning timing, direction, and magnitude. The trend-cycle component (Tt) represents variations of low frequency in a time series. Therefore, high-frequency fluctuations have been filtered out. The irregular component (It) of a time series is the residual time series after the trendcycle and the seasonal components have been removed. It corresponds to the high-frequency fluctuations of the series. Therefore, a seasonally adjusted time series data consists of only the trend cycle and irregular component. The procedure consists of the following main steps:

(i) Estimate the trend by a moving average and remove the trend leaving the seasonal and irregular components. 


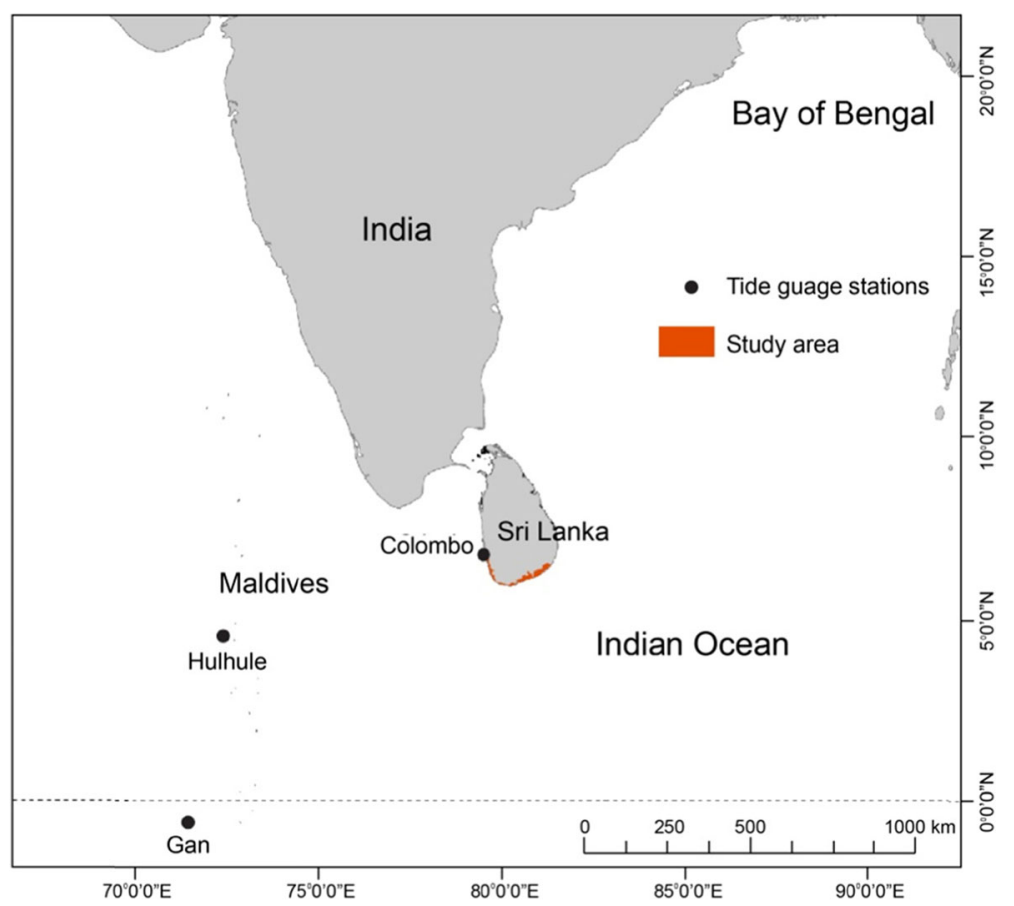

Fig. 1 Location of the study area in the central Indian Ocean

$$
\frac{O_{t}}{T_{t}}=\frac{T_{t} \times S_{t} \times I_{t}}{T_{t}} \approx S_{t} \times I_{t}
$$

(ii) Estimate the seasonal component using moving averages to smooth out the irregulars.

(iii) The preliminary estimation of adjusted data. An approximation of the seasonally adjusted series is found by dividing the estimate of the seasonal from the previous step into the original series.

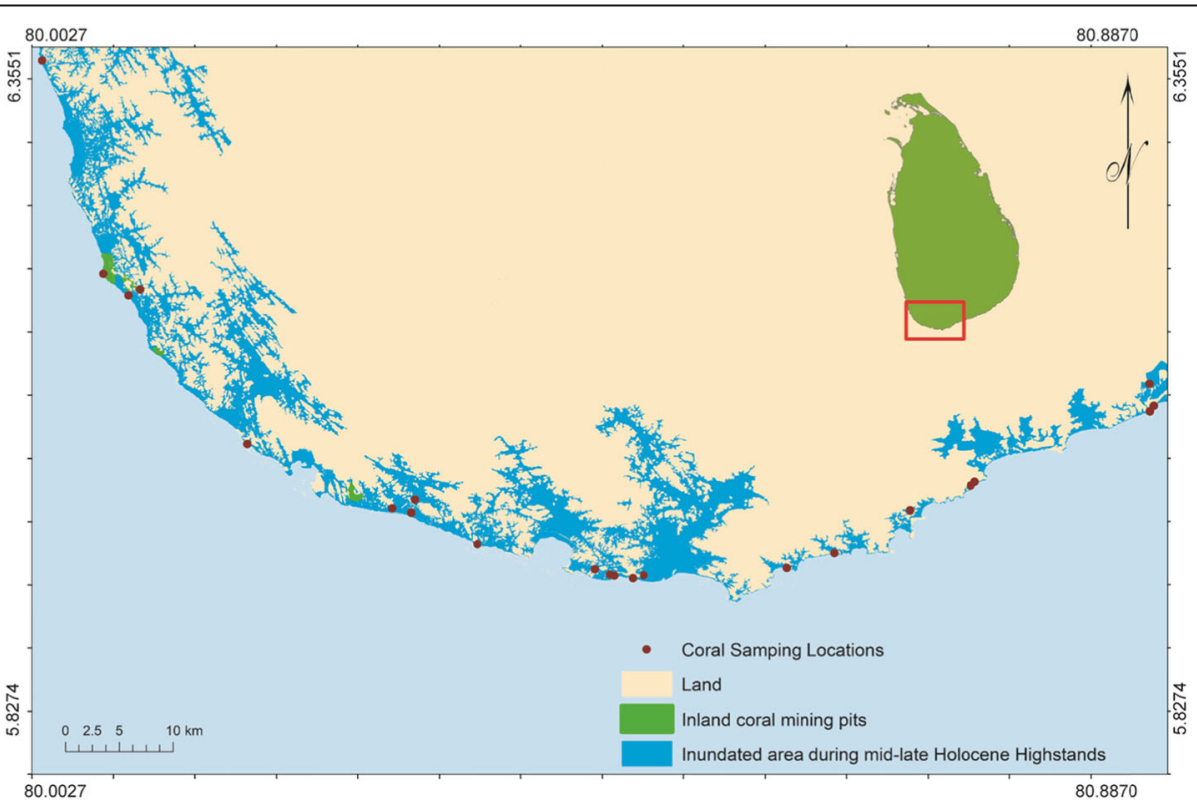

Fig. 2 Map of the study area showing the area for observed and estimated middle Holocene sea-level inundation based on paleo sea-level indications and highstands 


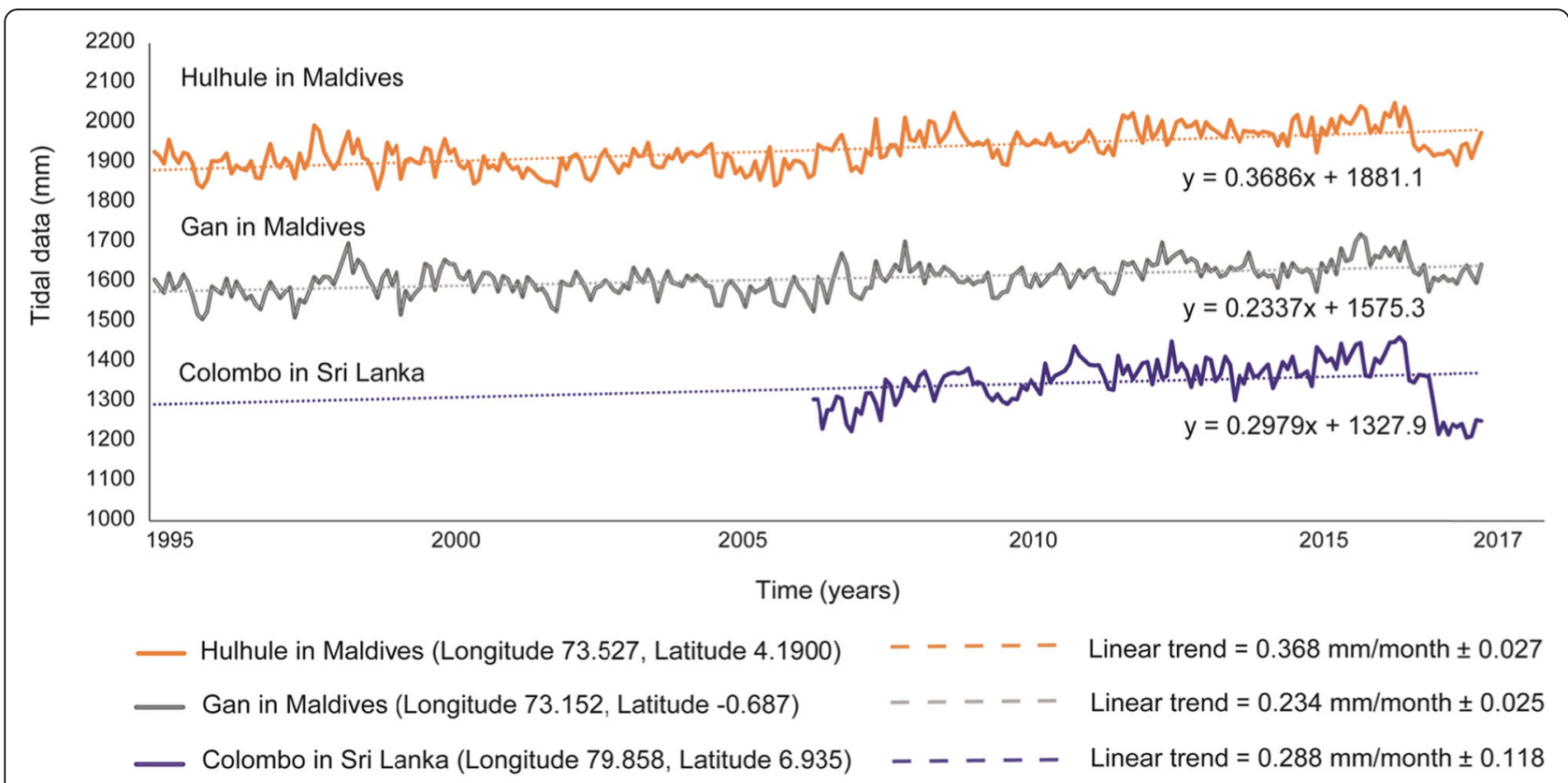

Fig. 3 Graph illustrating corrected data for seasonal component (solid lines), and the linear trend line (dotted lines) for the Hulhule and Gan tidal stations in the Maldives, and Colombo tidal station in Sri Lanka. (See appendix for original time series data and deseasonalized data)
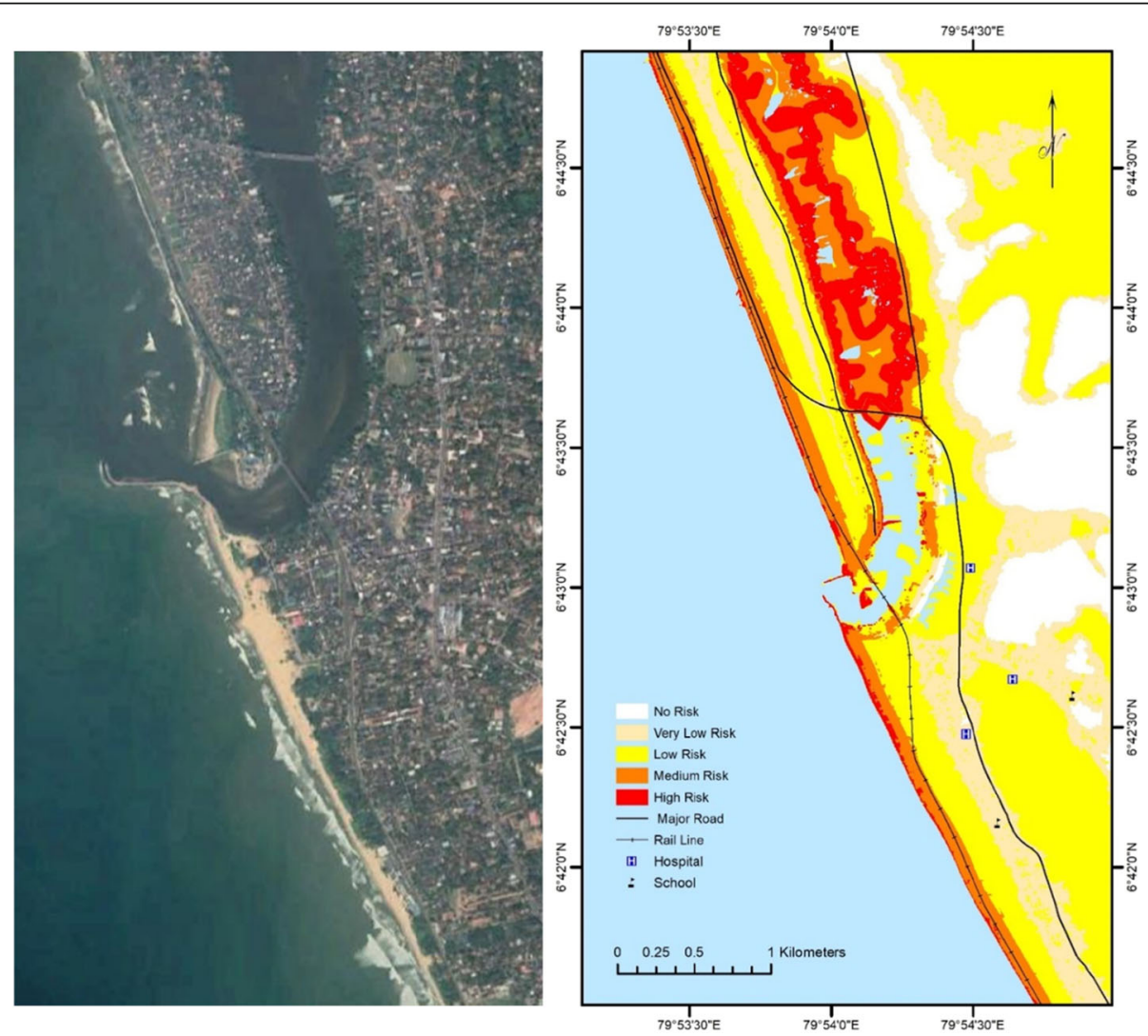

Fig. 4 (a) Satellite image of Panadura, and (b) risk assessment map of the area 


$$
\frac{O_{t}}{S_{t}}=\frac{T_{t} \times S_{t} \times I_{t}}{S_{t}} \approx T_{t} \times I_{t}
$$

(iv) Calculate the sea-level trend. Moving average is applied to the final estimate of the seasonally adjusted series, which has been corrected for extreme values. This gives an improved final estimate of the trend. Therefore, the calculated present annual sea-level trend was extended to determine the sea-level changes during the next 50 and 200 years.

\section{Digital elevation models (DEMs) and risk assessment}

The optical remote sensing method facilitates to acquire accurate $\mathrm{x}, \mathrm{y}, \mathrm{z}$ measurements of the Earth surface using laser light. The vertical resolution (in elevation) of the LiDAR data is $0.3 \mathrm{~m}$ and horizontal resolution is $1.0 \mathrm{~m}$. In this study, the LiDAR data obtained from the Survey Department of Sri Lanka was used to prepare DEMs for identifying morphological changes along the southwest to south coasts of Sri Lanka. Contour maps of 0.2 and $1.0 \mathrm{~m}$ intervals were considered before the preparation of risk assessment maps.

Coastal geomorphology (changes of elevations) was considered for the risk assessment maps. Risks followed by ocean wave behavior, bathymetry, and storm surge were given a minimum priority for the processing of risk assessment. However, it is important to note that these conditions can be changed within the next 200 years with the changes in ocean circulations, global wind patterns, and heat circulation. For future risk assessment, areas such as Panadura, Beruwala, Galle, and Matara were selected prioritizing the higher population density. The present risk assessment was carried out relative to sea-level changes during the next 200 years.
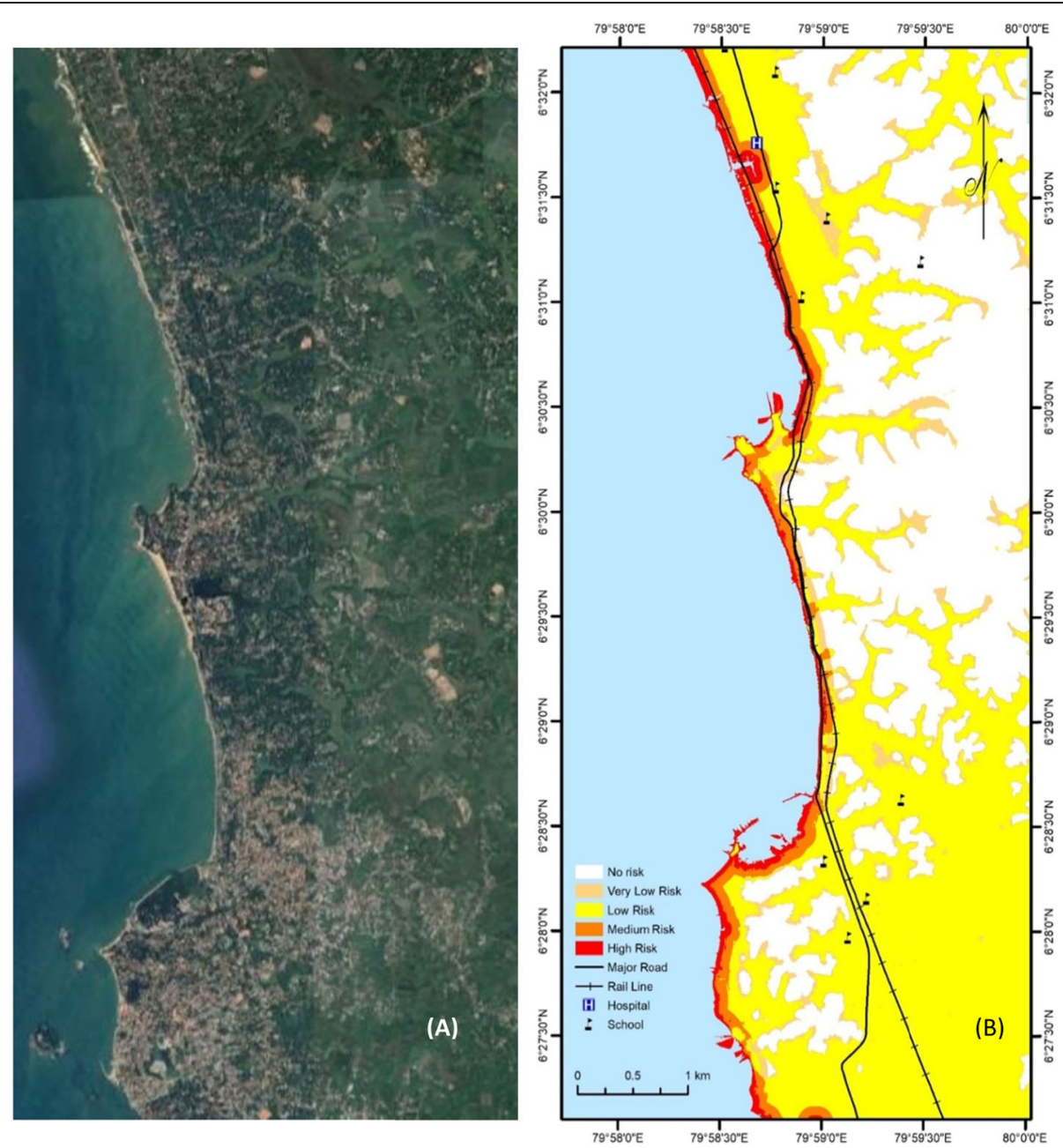

Fig. 5 (a) Satellite image of Beruwala, and (b) risk assessment map of the area 


\section{Results and discussion}

The middle Holocene Sea-level inundation

Figure 2 shows the determined possible sea-level inundation areas during the middle Holocene highstands. The south and southwest coasts of Sri Lanka consist of inland coral reefs submerged or exposed on the surface. Twenty-five inland coral sampling locations have been identified in the field excursions, and some of the inland coral and shell deposits were located about $1.5 \mathrm{~km}$ or more toward inland from the present coastline (Katupotha 1988a, 1988b; Katupotha and Fujiwara 1988). These paleo sea-level indicators have been used as a proxy to identify the mid-late Holocene sea-level highstands and inundation (Fig. 2). The field observations thus suggested that paleo sea-level highstands had prominently influenced the south and southwest coasts of Sri Lanka.

Several studies have discussed middle Holocene sealevel changes and geomorphological changes in Sri
Lanka (e.g., Katupotha 1988c, 1988d; Katupotha and Fujiwara 1988; Ranasinghe et al. 2013; Ratnayake et al. 2019; Yokoyama et al. 2019). For example, Katupotha and Fujiwara (1988) identified over $1.0 \mathrm{~m}$ sea-level highstands between 6.2-5.1 ky B.P. and 3.2-2.3 ky B. P along the southwest to south coasts of Sri Lanka. Ranasinghe et al. (2013) also concluded that mid-late Holocene highstands existed in southeastern Sri Lanka between $7.3 \mathrm{ky}$ and 3.0 ky B.P. Furthermore, Ratnayake et al. (2017) and Yokoyama et al. (2019) identified the teleconnection between the Antarctic melting history and sea-level changes in Sri Lanka and the Indian Ocean. In contrast, it is believed that the present coastal geomorphology of Sri Lanka was developed followed by Holocene sea-level regression about 2.5 cal ky B.P. (Katupotha 1988a, 1988b; Weerakkody 1992; Ratnayake et al. 2017). The present landscape is the indelible geomorphological imprint of past oscillations of sea-level. Consequently, paleo sea-level inundation and

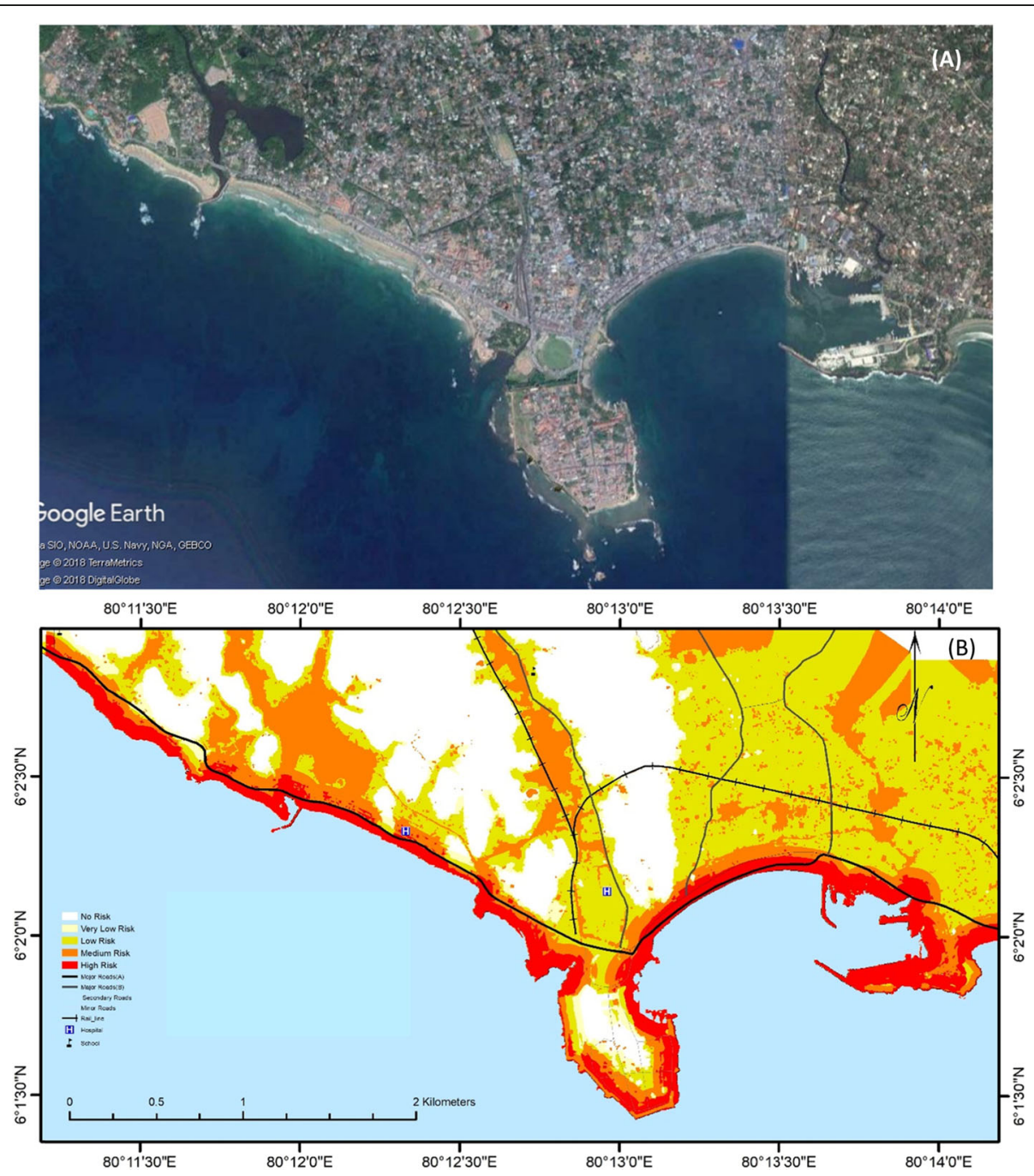

Fig. 6 (a) Satellite image of Galle, and (b) risk assessment map of the area 
landform evolutions can be used as the guide for quality assurance in future sea-level inundation in response to the present coastal zone, as discussed in 3.2 and 3.3.

\section{Modern Sea-level changes}

Tidal data of gauges in Colombo, Sri Lanka (period of 11 years, from 2006 to 2017), Gan, Maldives (period of 22 years, from 1995 to 2017), and Hulhule, Maldives (period of 22 years, from 1995 to 2017) are shown in Fig. 3. Sea-level variations in the central Indian Ocean based on tidal data show seasonal variations (Fig. 3). However, seasonally adjusted tidal gauge data of Colombo, Sri Lanka show that a sea-level has increased with a rate of $0.288 \pm 0.118 \mathrm{~mm} / \mathrm{month}$. Similarly, Hulhule and Gan stations in the Maldives also indicate that sea-levels have increased with a rate of $0.368 \pm 0.027 \mathrm{~mm} /$ month and $0.234 \pm 0.025 \mathrm{~mm} / \mathrm{month}$, respectively. Therefore, the authors calculated the average annual rate for predicting future sea-level height and inundation.

Sea-level is expected to rise by about $0.1 \mathrm{~m}-0.2 \mathrm{~m}$ during the next 50 years, which will result in an inundation of less than $1.8 \mathrm{~m}$ from the present sea-level towards the inland. Besides, sea-level is expected to rise by about $0.7 \mathrm{~m}$ during the next 200 years, with an inundation of $3.5-15.0 \mathrm{~m}$ from the present sea-level towards inland (not illustrated on the topographic map).
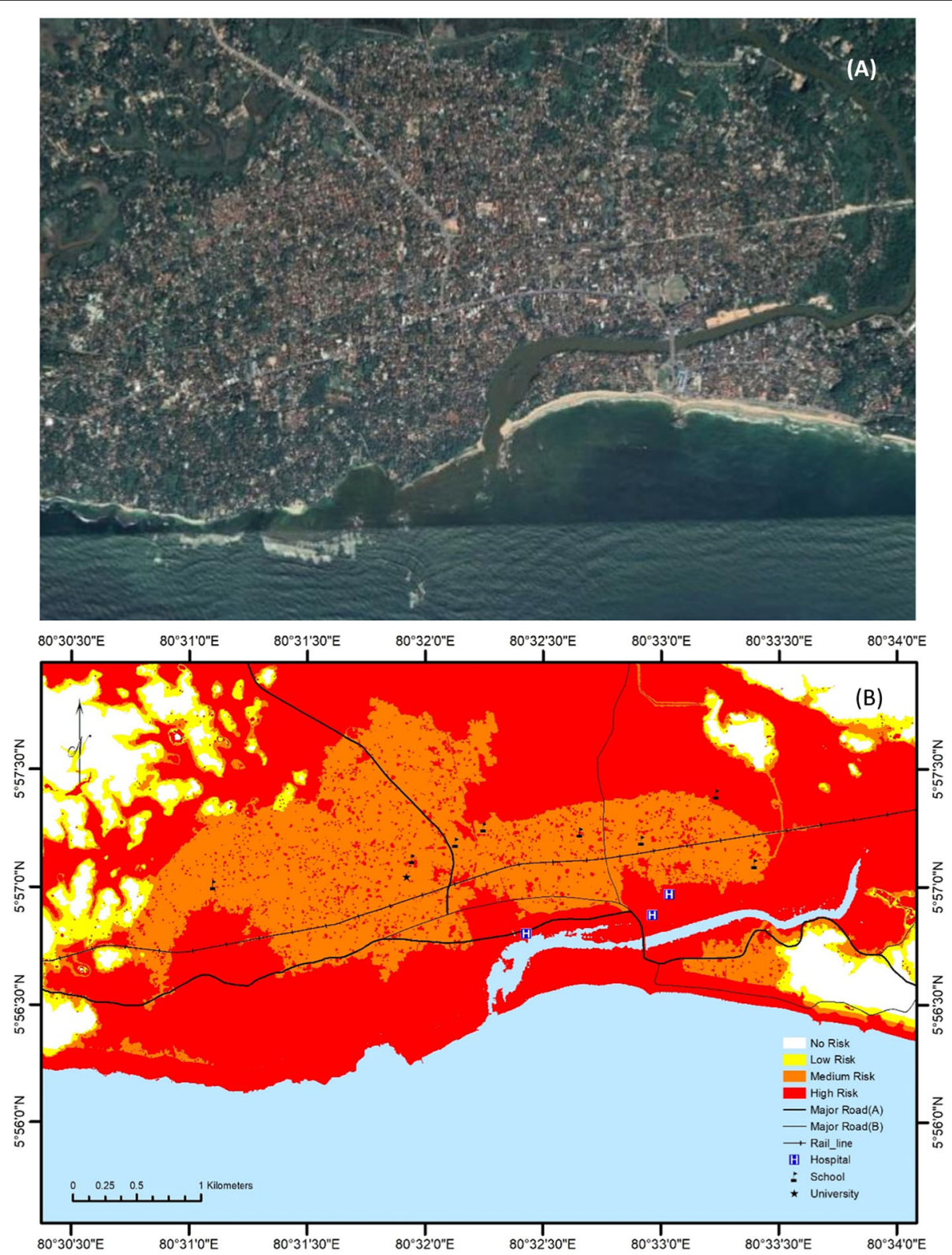

Fig. 7 (a) Satellite image of Matara, and (b) risk assessment map of the area 
Consequently, in this scenario, the gradual and cumulative erosion can be expected in the future along the south and southwest coasts of Sri Lanka. On the other hand, the predicted inundation distances from the present sea-level can be varied due to the influence of geologic setting and coastal geomorphological features such as rocky coastline, sandy ridges, lagoons, marshlands, buried coral reefs, and denudation hills, etc. Therefore, the scientific study of the coastal processes such as geomorphology is important to the identification of the danger or hazard zones in particular areas, as shown in the next section.

\section{Risk assessment}

Figures 4, 5, 6 and 7 show the risk assessment maps based on DEMs of Panadura, Beruwala, Galle, Matara areas, respectively. The red color indicates a high-risk area, whereas orange and dark yellow in colors shows medium and low-risk areas, respectively (Figs. 4 5, 6, 7). Besides, the white color area shows no risk areas. The sea-level inundation area was predicted as $0.086 \mathrm{~km}^{2}$ in the selected area of Galle for the next 200 years (Fig. 6). Similarly, sea-level inundation of Panadura, Beruwala, and Matara selected areas were predicted as $0.031 \mathrm{~km}^{2}$, $0.167 \mathrm{~km}^{2}$, and $0.103 \mathrm{~km}^{2}$, respectively (Figs. 4, 5 and 7). However, Matara is the most vulnerable area for future geoenvironmental disasters (Fig. 7), as the area has a very low elevation (1-3 m) up to considerable distance toward inland from the coast. These risk assessment maps suggest that the south and southwest coasts are more vulnerable to future sea-level inundation and possibly coastal erosions.

\section{Conclusions}

We have reconstructed the middle Holocene sea-level inundation boundary of the south and southwest coasts of Sri Lanka considering paleo sea-level indicators. Seasonally adjusted tidal gauge data in Colombo Sri Lanka (sea-level rising rate $=0.288 \pm 0.118 \mathrm{~mm} / \mathrm{month}$ ) suggested about $0.1-0.2 \mathrm{~m}$ inundation height during the next 50 years and about $0.7 \mathrm{~m}$ inundation height during next 200 years. Sea-level can be thus inundated about 3.5-15.0 m distance from the present sea-level. The progressive increase in sea-level can enhance coastal erosion along this coast. Consequently, the risk assessment maps can be implemented for geoenvironmental disaster management activities during future extreme events such as tsunami, and storms. Finally, it is recommended to study nearshore sediment dynamics and identify shore protection soft and hard engineering strategies/structures for controlling coastal erosion and future management strategies along the south and southwest coasts of Sri Lanka.

\section{Supplementary information}

Supplementary information accompanies this paper at https://doi.org/10. 1186/s40677-020-00154-y.

\section{Additional file 1. Appendix}

\section{Acknowledgements}

This study was financially supported by the University of Moratuwa Senate Research Capital Grant (Grant No: SRC/CAP/17/038). We would like to thank Ranjani Amarasinghe and Sadun Silva for supporting the field works.

\section{Authors' contributions \\ H.M. Ranjith Premasiri, Nalin Prasanna Ratnayake, Jinadasa Katupotha and Amila Sandaruwan Ratnayake obtained the research grant for this project, conceived of the presented idea, designed the theory of the project, and verified the analytical methods. Amila Sandaruwan Ratnayake, Lakshika Palamakumbure, Nimila Dushyantha, Shanaka Weththasinghe and Panchala Weerakoon carried out the experiments, performed the experimental calculations, produced maps, and interpreted the results. Lakshika Palamakumbure and Amila Sandaruwan Ratnayake wrote the manuscript with support from all the authors. All authors helped shape the research, analysis and manuscript, discussed the results, provided critical feedback and contributed to the final manuscript. All authors read and approved the final manuscript.}

Funding

University of Moratuwa Senate Research Capital Grant (Grant No: SRC/CAP/ 17/038).

\section{Availability of data and materials}

The raw datasets of the current study are available in the University of Hawaii Sea Level Center (UHSL) repository, and the analyzed datasets during the current study are available from the corresponding author on reasonable request.

\section{Competing interests}

The authors declare that they have no competing interests.

\section{Author details}

${ }^{1}$ Department of Earth Resources Engineering, Faculty of Engineering, University of Moratuwa, Katubedda 10400, Sri Lanka. ${ }^{2}$ Faculty of Applied Sciences, Uva Wellassa University, Passara Road, Badulla 90000, Sri Lanka. ${ }^{3}$ Ocean University of Sri Lanka, Crow Island, Mattakuliya, Colombo 01500, Sri Lanka. ${ }^{4}$ Department of Geography, University of Sri Jayewardenepura, Nugegoda 10250, Sri Lanka.

Received: 15 November 2019 Accepted: 6 May 2020

Published online: 12 May 2020

\section{References}

Amalan K, Ratnayake AS, Ratnayake NP, Weththasinghe SM, Dushyantha N, Lakmali N, Premasiri R (2018) Influence of nearshore sediment dynamics on the distribution of heavy mineral placer deposits in Sri Lanka. Environ Earth Sci 77:737. https://doi.org/10.1007/s12665-018-7914-4

Bindoff NL, Willebrand J, Artale V, Cazenave A, Gregory JM, Gulev S, Hanawa K, Le Quéré C, Levitus S, Nojiri Y, Shum CK (2007) Observations: oceanic climate change and sea level. In: Changes, pp 385-432

Caccamise DJ, Merrifield MA, Bevis M, Foster J, Firing YL, Schenewerk MS, Taylor FW, Thomas DA (2005) Sea level rise at Honolulu and Hilo, Hawaii: GPS estimates of differential land motion. Geophys Res Lett 32:L03607. https://doi. org/10.1029/2004GL021380

Domingues CM, Church JA, White NJ, Gleckler PJ, Wijffels SE, Barker PM, Dunn JR (2008) Improved estimates of upper-ocean warming and multi-decadal sealevel rise. Nature 453:1090-1093

Gregory JM, Church JA, Boer GJ, Dixon KW, Flato GM, Jackett DR, Lowe JA, O'farrell SP, Roeckner E, Russell GL, Stouffer R, Winton M (2001) Comparison of results from several AOGCMs for global and regional sea-level change 1900-2100. Clim Dyn 18:225-240

Han W, Meehl GA, Rajagopalan B, Fasullo JT, Hu A, Lin J, Large WG, Wang JW, Quan XW, Trenary LL, Wallcraft A, Shinoda T, Yeager S (2010) 
Patterns of Indian Ocean Sea-level change in a warming climate. Nat Geosci 3:546-550

He YH, Mok HY, Lai EST (2016) Projection of sea-level change in the vicinity of Hong Kong in the $21^{\text {st }}$ century. Int J Climatol 36:3237-3244

Hodgson ME, Bresnahan P (2004) Accuracy of airborne LiDAR derived elevation: empirical assessment and error budget. Photogramm Eng Remote Sensing 70:331-339

Huybrechts P, Goelzer H, Janssens I, Driesschaert E, Fichefet T, Goosse H, Loutre MF (2011) Response of the Greenland and Antarctic ice sheets to multimillennial greenhouse warming in the earth system model of intermediate complexity LOVECLIM. Surv Geophys 32:397-416

Kang SK, Cherniawsky JY, Foreman MG, Min HS, Kim CH, Kang HW (2005) Patterns of recent sea level rise in the east/Japan Sea from satellite altimetry and in situ data. J Geophys Res Ocean 110:C07002. https://doi.org/10.1029/2004JC002565

Katupotha J (1988a) Evidence of high sea level during the mid-Holocene on the southwest coast of Sri Lanka. Boreas 17:209-213

Katupotha J (1988b) Evolution of coastal landforms in the western part of Sri Lanka. Geogr Sci 43:18-36

Katupotha J (1988c) Hiroshima University radiocarbon dates I west and south coasts of Sri Lanka. Radiocarbon 30:125-128

Katupotha J (1988d) Hiroshima University radiocarbon dates II west and south coasts of Sri Lanka. Radiocarbon 30:341-346

Katupotha J, Fujiwara K (1988) Holocene Sea level change on the southwest and south coasts of Sri Lanka. Palaeogeogr Palaeoclimatol Palaeoecol 68:189-203

Li Y, Han W (2015) Decadal Sea level variations in the Indian Ocean investigated with HYCOM: roles of climate modes, ocean internal variability, and stochastic wind forcing. J Clim 28:9143-9165

Macaulay FR (1931) The smoothing of time series. Cambridge: NBER Books

Meier MF, Dyurgerov MB, Rick UK, O'Neel S, Pfeffer WT, Anderson RS, Anderson SP, Glazovsky AF (2007) Glaciers dominate eustatic sea-level rise in $21^{\text {st }}$ century. Science 317:1064-1067

Ranasinghe PN, Ortiz JD, Moore AL, McAdoo B, Wells N, Siriwardana CH, Wijesundara DT (2013) Mid-Late Holocene coastal environmental changes in southeastern Sri Lanka: new evidence for sea level variations in southern bay of Bengal. Quat Int 298:20-36

Ratnayake AS (2016) Evolution of coastal landforms during the Holocene epoch along the west and southeast coasts of Sri Lanka. Interdiscip Environ Rev 17:60-69

Ratnayake AS, Sampei Y, Ratnayake NP, Roser BP (2017) Middle to late Holocene environmental changes in the depositional system of the tropical brackish Bolgoda Lake, coastal Southwest Sri Lanka. Palaeogeogr Palaeoclimatol Palaeoecol 465:122-137

Ratnayake NP, Ratnayake AS, Azoor RM, Weththasinghe SM, Seneviratne IDJ, Senarathne $N$, Premasiri R, Dushyantha N (2019) Performance analysis of the beach nourishment and breakwater construction to control the coastal erosion at Uswetakeiyawa, Sri Lanka. SN Appl Sci 1:52. https:/doi.org/10.1007/s42452-018-0050-7

Ratnayake NP, Ratnayake AS, Keegle PV, Mallawa Arachchi MAKM, Premasiri HMR (2018) An analysis of beach profile changes subsequent to the Colombo Harbor expansion project, Sri Lanka. Environ Earth Sci 77:24. https://doi.org/ 10.1007/s12665-018-7234-8

Slangen ABA, Lenaerts JTM (2016) The sea level response to ice sheet freshwater forcing in the community earth system model. Environ Res Lett 11:104002. https://doi.org/10.1088/1748-9326/11/10/104002

Unnikrishnan AS, Shankar D (2007) Are sea-level-rise trends along the coasts of the North Indian Ocean consistent with global estimates? Glob Planet Change 57:301-307

Weerakkody U (1992) Geomorphology of the southern coastal plain. J Nat Sci Coun Sri Lanka 20:251-263

Wigley TML, Raper SCB (1987) Thermal expansion of sea water associated with global warming. Nature 330:127-131

Woodworth PL, White NJ, Jevrejeva S, Holgate SJ, Church JA, Gehrels WR (2009) Evidence for the acceleration of sea level on multi-decade and century timescales. Int I Climatol 29:777-789

Wunsch C, Stammer D (1997) Atmospheric loading and the oceanic "inverted barometer" effect. Rev Geophys 35:79-107

Yokoyama Y, Hirabayashi S, Goto K, Okuno Jl, Sproson AD, Haraguchi T, Ratnayake N, Miyairi Y (2019) Holocene Indian Ocean Sea level, Antarctic melting history and past tsunami deposits inferred using sea level reconstructions from the Sri Lankan, southeastern Indian and Maldivian coasts. Quat Sci Rev 206:150-161

\section{Publisher's Note}

Springer Nature remains neutral with regard to jurisdictional claims in published maps and institutional affiliations.

\section{Submit your manuscript to a SpringerOpen ${ }^{\circ}$ journal and benefit from:}

- Convenient online submission

- Rigorous peer review

- Open access: articles freely available online

- High visibility within the field

- Retaining the copyright to your article

Submit your next manuscript at $\boldsymbol{\nabla}$ springeropen.com 